\title{
Optimalisasi Kemampuan Guru Melalui Pelatihan Kuis Interaktif Secara Daring Berbasis Teknologi Informasi
}

\author{
Optimizing Teacher Ability Through Online Interactive Quiz Training Based on \\ Information Technology
}

\author{
Adhy Kurnia Triatmaja*1, Mentari Eka Wahyuni ${ }^{2}$, Barry Nur Setyanto ${ }^{3}$, Rio Tirta \\ Sudarma ${ }^{4}$, Waznan Fauzi Oktavian ${ }^{5}$ \\ Universitas Ahmad Dahlan, Yogyakarta, Indonesia \\ *Penulis Korespondensi

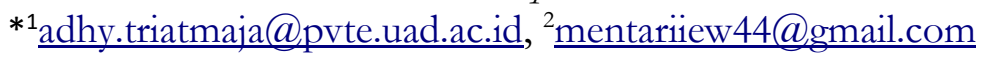

Riwayat Artikel: Dikirim 10 Juni 2021; Diterima 2 September 2021; Diterbitkan 30 November 2021

\begin{abstract}
Abstrak
Pemanfaatan teknologi sangat berperan penting dalam pembelajaran di era pandemi. Berbagai upaya dilakukan guna membekali para guru untuk dapat mengoptimalkan penggunaan media pembelajaran. Salah satu upaya tersebut yaitu dengan menyelenggarakan pelatihan pembuatan kuis interaktif secara daring berbasis teknologi informatika yang dilaksanakan di SMP Negeri 1 Jaten. Pelatihan ini bertujuan untuk memberikan wawasan terkait media pembelajaran Kahoot!, Google Form, dan Quiriz:. Metode yang dilakukan dalam pelatihan ini terdiri atas tiga tahapan yaitu persiapan, pelaksanaan dan evaluasi. Pelatihan ini dilakukan pada 6 Mei - 7 Mei 2021 dan diikuti oleh 32 guru kelas VII, VIII dan IX yang terdiri atas para guru mata pelajaran. Hasil dari kegiatan pelatihan ini yaitu guru memahami materi pelatihan dengan baik sehingga semua informasi yang didapatkan dapat secara langsung dipraktekkan. Guru mendapatkan materi yang sangat relevan dengan kebutuhan di kelas dan dapat menunjang kegiatan pembelajaran. Selain itu, guru mendapatkan wawasan baru terkait media pembelajaran yang dapat diterapkan dalam menyusun kuis interaktif secara kreatif dan inovatif.
\end{abstract}

Kata kunci: Kuis Interaktif, Daring, Teknologi informatika.

\begin{abstract}
The use of technology is very important in learning in the pandemic era. Various efforts were made to equip teachers to optimize the use of learning media. One of these efforts is to organize training on making interactive quizzes based on information technology which is beld at SMP Negeri 1 Jaten. This training aims to provide insight related to learning media so that teachers are able to improve their abilities in making interactive quizzes and have a good impact on the future learning process. The method used in this training consists of three stages, namely preparation, implementation and evaluation.This training was conducted on May 6-May 7, 2021 and was attended by 32 teachers for grades VII, VIII and IX consisting of subject teachers. The result of this training activity is that the teacher understands the training material well so that all the information obtained can be directly put into practice. Teachers get material that is very relevant to the needs in the classroom and can support learning activities. In addition, teachers get new insights related to learning media that can be applied in preparing interactive quizzes creatively and innovatively.
\end{abstract}

Keywords: Interactive quizzes, Online, Information technology

\section{PENDAHULUAN}

Kuis interaktif merupakan suatu permainan yang memberikan kesempatan kepada pemain dan semua peserta bahkan penonton untuk melakukan upaya kreatif (Untari, 2015). Pemberian kuis merupakan strategi dari seorang guru terhadap peserta didik setelah proses pembelajaran 
dilaksanakan. Hal ini bertujuan untuk mengetahui dan mengukur tingkat pemahaman peserta didik.

Berbagai tantangan harus dihadapi oleh guru di masa pandemi Covid-19. Pandemi ini telah mempengaruhi semua sektor, terutama dalam sektor pendidikan yang melibatkan kegiatan pembelajaran didalamnya. Pembelajaran secara daring merupakan suatu pilihan yang telah diterapkan di sekolah sebagai upaya pencegahan Covid-19 (Nur Hidayat et al., 2020). Berbagai fasilitas untuk mendukung kegiatan pembelajaran secara daring telah diupayakan oleh pihak guru dan sekolah. Selain itu, kegiatan tatap muka antara pihak satu dengan pihak lain dalam lingkup sekolah telah diupayakan untuk diganti dengan menggunakan metode baru seperti konferensi secara online. Hal ini menyebabkan kebutuhan akses internet semakin meningkat.

Penggunaan perangkat keras seperti PC dan smartphones sangat berperan penting dalam proses pembelajaran secara daring. Pada perangkat tersebut dapat dijadikan sebagai media pembelajaran. Kebutuhan suatu media pembelajaran yang interaktif dapat meningkatkan minat belajar para siswa (Chaiyo \& Nokham, 2017). Dalam hal membangun minat belajar siswa, penggunaan media yang interaktif menjadi hal yang perlu dicermati oleh para guru. Guru harus mampu mengembangkan kreativitas dan inovasi sehingga tercipta situasi belajar yang menyenangkan bagi siswa. Oleh karena itu, wawasan guru mengenai media pembelajaran perlu ditingkatkan dengan harapan guru mampu memanfaatkan media secara tepat dan efisien.

Suatu proses pembelajaran memiliki beberapa tahapan salah satunya yaitu penilaian akhir. Penilaian akhir bertujuan untuk mengetahui sejauh mana pemahaman siswa terhadap materi yang telah disampaikan oleh guru. Teknologi informatika dapat dimanfaatkan dalam merancang sebuah kuis interaktif yang bisa dijadikan sebagai bahan penilaian akhir. Beberapa aplikasi yang dapat digunakan seperti Kahoot!, Google Form, dan Quiriz:

Kahoot! merupakan suatu media pembelajaran interaktif berbasis game yang dapat digunakan pada perangkat apapun. Konsep game pada Kahoot! dirancang untuk menarik partisipasi siswa dalam belajar (Adnyani et al., 2020). Guru dan siswa harus memiliki perangkat masing-masing ketika bermain dengan Kahoot!. Kahoot! disediakan untuk membuat kuis termasuk menambahkan elemen-elemen seperti gambar dan video YouTube. Saat bermain, guru berperan menampilkan Kahoot! pada layar dengan pertanyaan-pertanyaan yang sudah dipersiapkan. Para siswa tidak harus memiliki sebuah akun, namun siswa dapat masuk ke dalam permainan dengan sebuah kode dan nama masing-masing siswa. Ketika pertanyaan ditampilkan oleh guru, siswa dapat menekan tombol warna sesuai dengan jawaban yang mereka pilih. Pada layar telah diatur waktu yang akan dihitung mundur hingga waktu yang ditentukan habis. Semua jawaban siswa secara langsung tampil di layar. Kahoot! menyediakan musik yang dapat didenger sehingga permainan terkesan menyenangkan (Chaiyo \& Nokham, 2017). Quiziz: memiliki kesamaan dengan Kahoot! seperti guru mempersiapkan permainan berupa kuis dan disediakan kode untuk setiap siswa. Namun, terdapat sedikit perbedaan antara keduanya yaitu siswa dapat melihat pertanyaan yang disediakan oleh guru pada layar masing-masing dan siswa secara langsung dapat memilih jawaban yang benar. Pertanyaan yang tampil pada layar setiap siswa ditampilkan secara acak sehingga siswa tidak dapat mencontek jawaban dari siswa yang lain. Pada Quizizz, siswa tidak perlu untuk menunggu seluruh siswa menjawab karena di masing-masing layar siswa telah disediakan waktu yang telah ditentukan. Quizizz menjadikan kegiatan pembelajaran menjadi lebih interaktif (Junior, 2020). Google 
Form merupakan aplikasi berbasis web yang memfasilitasi guna survey online, kuesioner dan kuis. Guru dapat melakukan penilaian dengan sejumlah pertanyaan yang dicantumkan pada Google Form. Siswa dapat memberi tanggapan berupa jawaban yang dapat dikompilasi ke dalam spreedsheet untuk kemudian dianalisis oleh guru. Pemberian kuis ini diharapkan dapat mendorong peserta didik dalam mempersiapkan diri di rumah untuk belajar sebelum masuk kelas. Melalui pemberian kuis diperoleh timbal balik atau feedback (Riskawati, 2017).

Pemanfaatan aplikasi Kahoot!, Google Form, dan Quiziz: belum dioptimalkan di SMP N 1 Jaten. Pembelajaran secara daring di sekolah tersebut sudah baik namun dalam hal evaluasi pembelajaran, para guru hanya menggunakan Google Classroom. Pemberian kuis dilakukan secara manual dengan cara mengirimkan file PDF kepada siswa. Oleh karena itu, perlu adanya peningkatan wawasan dan kemampuan guru dalam memanfaatkan media pembelajaran terutama dalam membuat suatu kuis interaktif berbasis teknologi informatika. Upaya yang dapat dilakukan yaitu dengan memperkenalkan media pembelajaran yang inovatif melalui kegiatan Pelatihan Kuis Interaktif secara Daring Berbasis Teknologi Informatika untuk Guru SMP Negeri 1 Jaten. Kegiatan ini bertujuan untuk memberikan wawasan terkait media pembelajaran sehingga mampu meningkatkan kemampuan guru di SMP Negeri 1 Jaten dalam membuat kuis interaktif dan memberikan dampak yang baik untuk proses pembelajaran kedepannya.

\section{METODE}

Pelatihan pembuatan kuis interaktif dilakukan secara luring pada tanggal 6 Mei 2021 sampai 7 Mei 2021 di SMP Negeri 1 Jaten. Peserta pelatihan terdiri atas semua guru mata pelajaran. Tahapan pelatihan dibagi menjadi tiga yaitu persiapan, pelaksanaan dan evaluasi. Pada tahap persiapan, materi akan ditentukan dan disesuaikan dengan analisis situasi pada sekolah mitra. Materi yang akan disampaikan meliputi Kahoot!, Google Form, dan Quiziz:. Kemudian diadakan sosialisasi dari kegiatan pelatihan yang akan dilakukan kepada para guru. Selain itu, perlu dilakukan koordinasi kepada Kepala Sekolah SMP N 1 Jaten terkait waktu pelaksanaan pelatihan. Pada tahap pelaksanaan, terdapat beberapa kegiatan diantaranya: 1) Pengenalan aplikasi Kahoot! oleh pemateri dan pembuatan kuis interaktif dengan Kahoot! oleh para peserta pelatihan, 2) Pengenalan aplikasi Google Form oleh pemateri dan pembuatan kuis interaktif dengan Google Form, 3) Pengenalan aplikasi Quizizz dan pembuatan kuis interaktif dengan Quiziž, dan 4) Sinkronisasi aplikasi Kahoot!, Google Form, dan Quizizz dengan Google Classroom atau e-learning yang digunakan di sekolah. Pada tahap evaluasi, semua peserta mengisi angket kepuasan pelatihan kuis interaktif yang dapat diisi melalui Google Form.

\section{HASIL DAN PEMBAHASAN}

Pelaksanaan pelatihan dilaksanakan secara daring yang diikuti oleh semua guru mata pelajaran di SMP Negeri 1 Jaten berjumlah 32 orang. Materi yang disampaikan berbasis pada teknologi informatika dengan memanfaatkan beberapa aplikasi yaitu Kahoot!, Google Form, dan Quiziz: Kegiatan pelatihan dapat dilihat pada Gambar 1.

Gambar 1:

Materi pelatihan disampaikan oleh pemateri

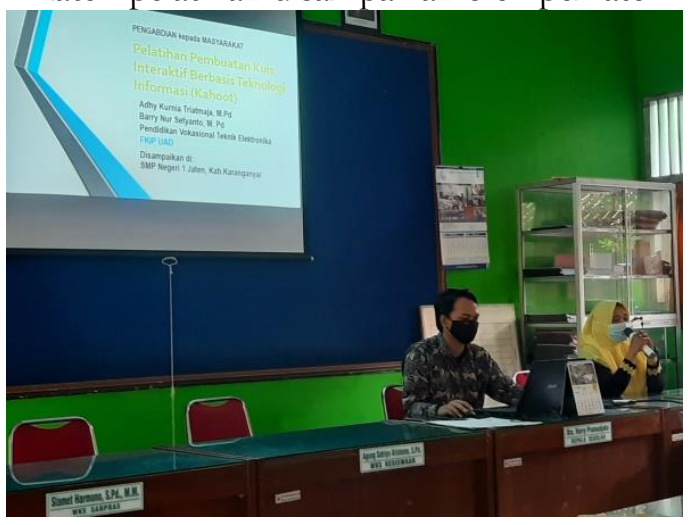

Sumber: Dokumentasi Pribadi 
Selama kegiatan berlangsung, dilakukan diskusi dan tanya jawab sehingga semua peserta dapat menyampaikan hal yang belum dipahami dalam pelatihan. Antusiasme guru dalam mendengarkan materi yang disampaikan pemateri dapat dilihat pada Gambar 2

\section{Gambar 2:}

Antusiasme guru dalam pelatihan kuis interaktif

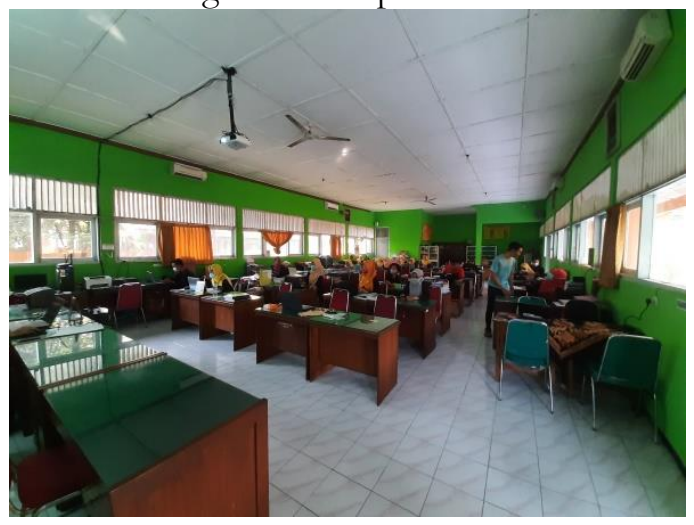

Sumber: Dokumentasi Pribadi

Pada akhir pelatihan dilakukan evaluasi berupa angket yang dibagikan melalui Google Form. Berdasarkan hasil angket, penggunaan aplikasi yang sering digunakan guru di sekolah dalam memberikan soal kepada siswa yaitu pada aplikasi Google Classroom, e-learning sekolah, Ukline dan Indoprima. Penggunaan Google Classroom menunjukkan persentase sebesar 69\%. Hal ini menunjukkan bahwa para guru sering menggunakan media ini dalam kegiatan pembelajaran terutama pemberian soal di sekolah. Selain itu, e-learning sekolah, Ukline dan Indoprima juga dimanfaatkan dalam menunjang kegiatan pembelajaran. Persentase penggunaan aplikasi tersebut dapat dilihat pada Grafik 1.
Grafik 1:

Penggunaan aplikasi yang digunakan para guru di sekolah

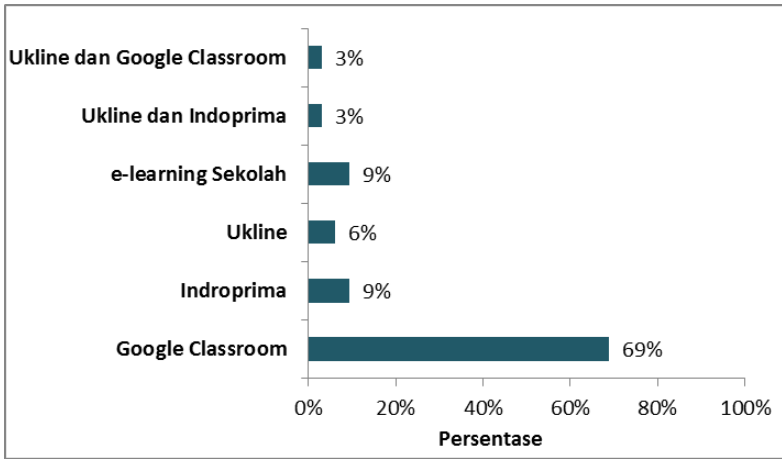

Penggunaan Kahoot!, Google Form, Quiziz:, di SMP Negeri 1 Jaten belum diterapkan di sekolah sehingga dilakukan sebuah pelatihan kuis interaktif yang memanfaatkan aplikasi tersebut. Pelatihan kuis interaktif yang telah dilakukan dapat mendukung profesi guru. Hal ini dapat dibuktikan dengan pernyataan sangat setuju yang mendapatkan persentase sebesar $66 \%$, setuju 31\% dan netral sebesar 3\%. Melalui pelatihan ini dapat memotivasi guru untuk beradaptasi dengan perkembangan teknologi sehingga dapat sejalan dengan proses pembelajaran. Hal ini akan berdampak pada sistem evaluasi pembelajaran yang dapat dikembangkan secara efektif dan efisien. Persentase perolehan angket dapat dilihat pada Grafik 2.

Grafik 2:

Pelatihan kuis interaktif mendukung profesi guru

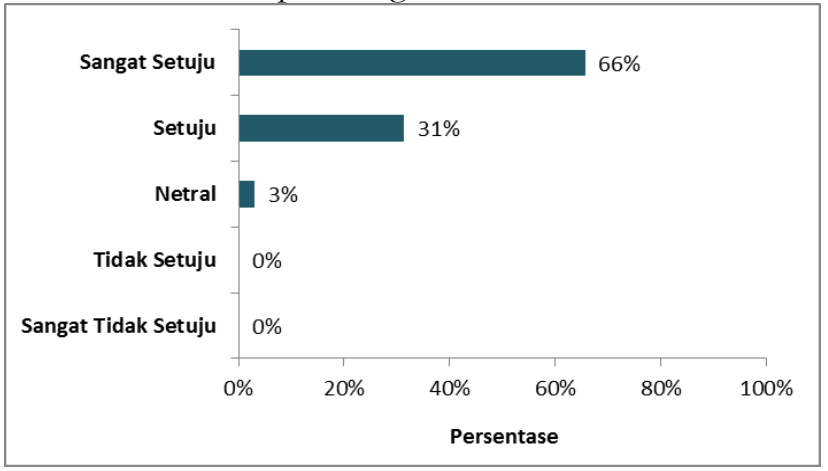


Pelatihan kuis interaktif yang telah dilakukan dapat menambah wawasan para guru. Hal ini dibuktikan dengan pernyataan sangat setuju yang mendapatkan persentase sebesar 66\%, setuju 31\% dan netral sebesar $3 \%$. Melalui pelatihan kuis interaktif, wawasan guru dapat bertambah dalam mengembangkan media pembelajaran secara kreatif dan inovatif sesuai dengan karakteristik siswa. Persentase perolehan angket dapat dilihat pada Grafik 3.

Grafik 3:

Pelatihan kuis interaktif menambah wawasan para guru

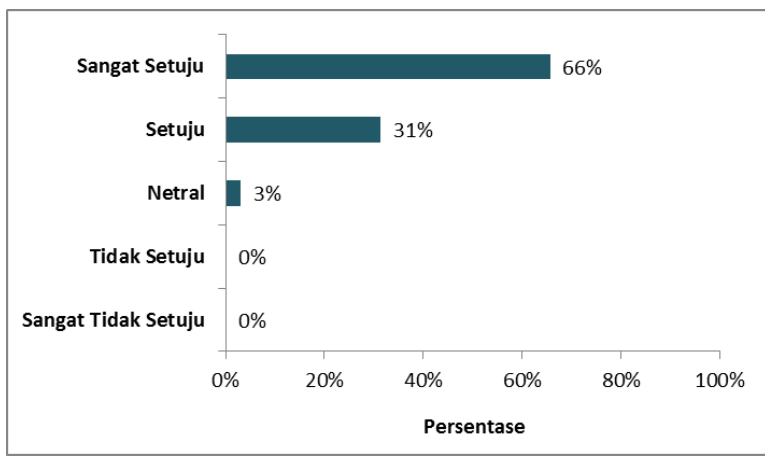

Pelatihan kuis interaktif dapat meningkatkan keterampilan para guru. Hal ini dibuktikan dengan pernyataan sangat setuju yang mendapatkan persentase sebesar $72 \%$, setuju 25\% dan netral sebesar 3\%. Melalui pelatihan kuis interaktif, guru dapat merancang suatu media pembelajaran berbasis teknologi informatika sehingga proses belajar mengajar lebih optimal dan menarik. Selain itu, guru dapat mengekspresikan diri dengan mencoba halhal baru. Persentase perolehan angket dapat dilihat pada Grafik 4.
Grafik 4:

Pelatihan kuis interaktif meningkatkan keterampilan para guru

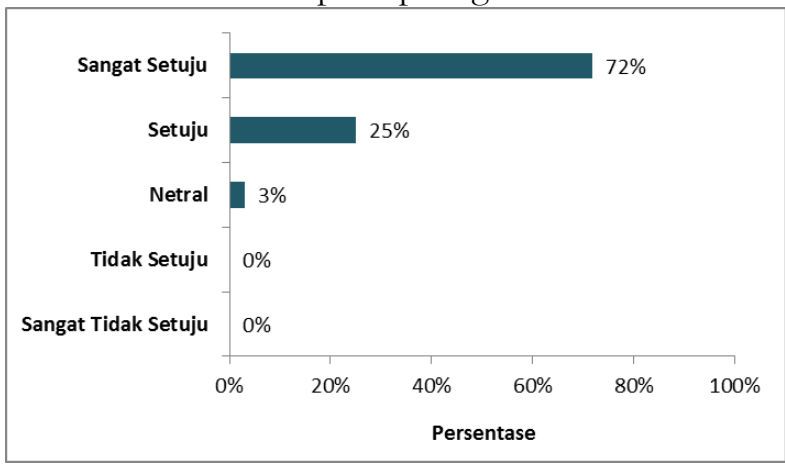

Materi pelatihan kuis interaktif yang diberikan mudah dipahami oleh para guru. Hal ini dibuktikan dengan pernyataan sangat setuju yang mendapatkan persentase sebesar $47 \%$, setuju $47 \%$ dan netral sebesar $6 \%$. Pelatihan dilakukan dengan penyampaian materi yang sejalan dengan diskusi dan tanya jawab antara pemateri dengan para guru sehingga mempermudah guru memahami materi. Melalui materi pelatihan kuis interaktif yang mudah dipahami membuat para guru dapat berkolaborasi dan bekerja sama dalam tim dengan baik. Persentase perolehan angket dapat dilihat pada Grafik 5.

Grafik 5:

Materi pelatihan kuis interaktif mudah dipahami

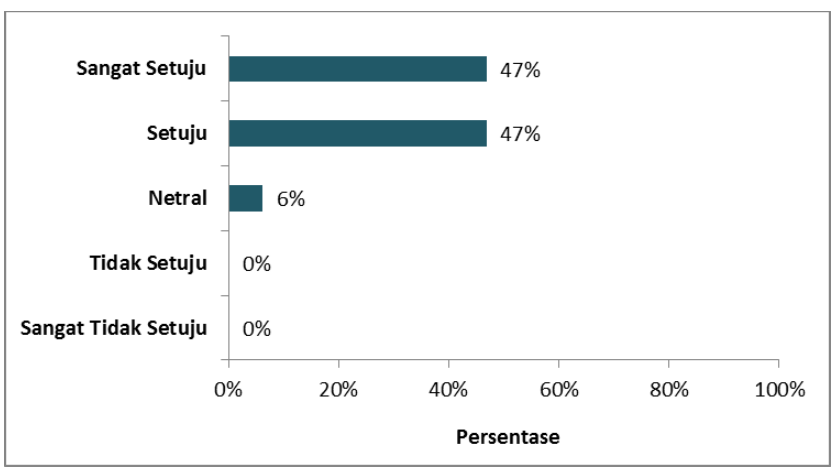


Penggunaan media evaluasi yang selama ini digunakan oleh para guru di SMP N 1 Jaten yaitu Google Classroom, Ukline, Indoprima dan e-learning yang disediakan oleh sekolah. Upaya untuk meningkatan kemampuan guru dalam mengoptimalkan pembelajaran daring yaitu dengan memberikan pelatihan terkait sistem evaluasi yang selama ini belum pernah digunakan sebelumnya seperti Kahoot!, Google Form, dan Quiziz: Melalui media tersebut, guru mendapatkan pengetahuan baru dalam merancang sebuah sistem evaluasi yang efektif dan efisien dan tentunya bermuara terhadap peningkatan kualitas pembelajaran.

Proses pelatihan kuis interaktif sangat membantu guru dalam mengeksplorasi halhal baru sehingga guru dapat belajar dan merancang suatu media pembelajaran dengan kreatif dan inovatif. Hal ini sejalan dengan penelitian yang dilakukan oleh Pentury dkk. (2021) bahwa guru memperoleh kesempatan dalam membangun sendiri pengetahuannya sehingga mendapatkan pemahaman dan pengalaman yang mendalam. Selain itu, guru dapat mengatasi keterbatasan pengalaman mereka dalam menggunakan teknologi informatika. Penggunaan media dalam kuis interaktif membuka wawasan kepada para guru bahwa teknologi informatika memberikan peluang yang lebih efektif dan fleksibel dalam pembelajaran daring (Hofmeister \& Pilz, 2020). Pemanfaatan media berbasis teknologi informatika dalam rangka meningkatkan efektifitas proses pembelajaran diharapkan bermuara pada meningkatnya minat belajar siswa.

Dalam Kegiatan Pelatihan tersebut terdapat beberapa kendala yang dialami, seperti koneksi internet yang kurang memadai untuk kebutuhan semua guru-guru ketika melakukan praktik, serta kemampuan memahami materi yang diberikan berbedabeda dan tergolong lambat karena sebagian besar guru sudah berumur.

\section{KESIMPULAN}

Kegiatan pelatihan pembuatan kuis interaktif berbasis teknologi informatika telah dilakukan dengan memanfaatkan aplikasi Kaboot!, Quiziz: Google Form. Melalui kegiatan tersebut, para guru secara mandiri mampu menyusun kuis interaktif yang manarik, interaktif dan efektif sehingga akan terbentuk sebuah bahan penilaian akhir yang variatif dan menyenangkan.

Semua guru yang mengikuti kegiatan ini sangat termotivasi untuk membuat kuis interaktif yang nantinya bisa diterapkan kepada peserta didik. Sebagian besar guru bahkan langsung mengimplementasikan kuis yang telah dibuat kepada siswa. Pelatihan ini memberikan materi yang relevan dengan kebutuhan guru dan dapat menunjang kegiatan pembelajaran

\section{DAFTAR PUSTAKA}

Adnyani, K. E. K., Adnyana, I. W., \& Murniasih, N. N. (2020). Teacher and Students' Perception on Using Kahoot! for English Learning. 394(Icirad 2019), 6267.

https://doi.org/10.2991/assehr.k.200 115.011

Chaiyo, Y., \& Nokham, R. (2017). The effect of Kahoot, Quizizz and Google Forms on the student's perception in the classrooms response system. 2nd Joint International Conference on Digital Arts, Media and Technology 2017: Digital Economy for Sustainable Growth, ICD AMT 2017, 178-182. https://doi.org/10.1109/ICDAMT.20 17.7904957 
Hofmeister, C., \& Pilz, M. (2020). Using ELearning to Deliver In-Service Teacher Training in the Vocational Education Sector: Perception and Acceptance in Poland, Italy and Germany. Education Sciences, $10(7), \quad 182$. https://doi.org/10.3390/educsci10070 182

Junior, J. B. B. (2020). Assessment for Learning With Mobile Apps: Exploring the Potential of Quizizz in the Educational Context. International Journal of Development Research, 10(1), 33366-33371.

Nur Hidayat, W., Suswanto, H., Wijaya Kristanto, C., Pramudya Wardhani, A., Hamdan, A., \& Kartika Sari, R. (2020). The effectiveness of interactive digital evaluation training for improving teacher skills in the covid-19 pandemic period. 4th International Conference on Vocational Education and Training, ICOVET 2020, 310-314. https://doi.org/10.1109/ICOVET502 58.2020 .9230070

Pentury, H. J., Rangka, I. B., Anggraeni, A. D., \& Korespondensi, P. (2021). Peningkatan Kemampuan Pedagogike Guru dalam Pembelajaran Daring melalui Penerapan Kuis Interaktif Daring. 3(2), 109-114.

Riskawati. (2017). Pengaruh Pemberian Kuis pada Proses Pembelajaran Fisika terhadap Hasil Belajar Peserta Didik kelas XI SMKN 4 Bulukumba. Jurnal Pendidikan Fisika Universitas Mubammadiyah Makassar, 2, 90-98.

Untari, E. (2015). Efektivitas Metode kuis Interaktif dan Explicit Intruction pada Prestasi Belajar Mahasiswa STKIP PGRI Ngawi. Media Prestasi: Jurnal Kependidikan STKIP PGRI Ngawi. 